\title{
Legislação especial sôbre delitos de automovel
}

\author{
Cadeira: Direito Penal Comparado \\ Professor: Doutor Noé Azevedo \\ Aluno: Vicente de Paulo Vicente de Azevedo

\section{UM PROJETO ESQUECIDO}

Haviamos escolhido para tema desta tese uma apreciação sobre culpa penal; e pretendiamos, em rapido escorço, procurar a linha de distinção entre a culpa penal e a culpa civil.

Recordando, entretanto, ligeiramente o assunto reconhecêmos, á vista da evolução juridica e doutrinária moderna que, dentro em breve as questões relativas á culpa, atual fundamento da responsabilidade, tomarão o caminho das indagações de interêsse histórico. Realiza-se a predição de Ihering: "A historia da culpa se resume na sua constante abolição".

Acorreu-nos então, que sería de mais interêsse um breve apanhado sôbre o que se fez até hoje, em nosso país no sentido da renovação ou substituição do princípio da culpa, como fundamento da responsabilidade; especialmente no que diz respeito aos delitos originados do transporte.

Tradicional, vindo dos romanos, o princípio da culpa ainda hoje domina todas as legislações dos paises cultos. 
Representára grande progresso, porque, traço carateristico do direito romano antigo é a nenhuma importancia atribuida á intenção ou á culpa: pela lei das doze táboas, o causador das lesões corporais, inocente ou culpado, se não transigísse, sofria a pena de talião. Responsabilidade puramente objetiva. Só mais tarde é que foi sujeito á composição forçada.

$\mathrm{Na}$ lei das doze táboas aparecíam disposições sôbre o damnum injuria datum; igualmente em outras leis antigas. Tanto uma como outras foram, em o novo direito romano, revogadas pela Lex Aquilia.

Disto nos dá conta e notícia o texto de Ulpiano: Lex Aquilia omnibus legibus quae ante se de damno injuriae lucutae sunt, derogaverit, sive XII Tabulis, sive alia quae fuit; quas leges nunc refere non esse necesse (1).

Era a lei Aquilia no seu teôr primitivo de aplicação muitissimo restrita, pois a actio legis Aquiliae não competia sinão ao proprietario e somente por um damnum corpore corporis datum.

A mesma ação, entretanto, foi sob a forma de actio in fatum ou utilis atribuida a outras pessoas que houvessem sofrido prejuizo, e a outros gêneros de dano. E, posto não tivesse por fim especial a reparação do mal causado, a actio legis Aquiliae era considerada de natureza penal como uma actio rei et poenae persecutoria.

Assim, aquele que, por meio de ato, injustamente, contra o direito, - injúria - por dólo ou culpa, ainda mesmo levissima, causasse prejuizo a outrem em sua pessoa ou bens, cometia o delito denominado damnum injuriae datum.

O titulo quinto das Institutas, livro $4 .^{\circ}$ reza: De obligationibus quae quasi ex delicto nascuntur.

Nas Institutas cinco são as especies de obrigações $e x$ delicto, dentre as quais cumpre destacar: a ação contra aquele de cuja casa se atirou ou despejou qualquer cousa sôbre a rua ou passagem pública resultando dano para o transeunte; a ação popular para solicitar pena privada contra aquele que coloca ou suspende um objéto sobre uma passagem, ubi vulgo iter fit, de forma a comprometer a segurança dos peões; 
a ação para obter indenização pecuniaria contra o nauta, o caupo ou o stabularius, quando seus prepostos houvessem ocasionado por furto ou qualquer outro dólus, um prejuizo aos passageiros ou viajantes; e finalmente as ações noxais pelas quais o senhor podia ser acionado como responsavel pelo dano causado por seu escravo, sem sua ordem, e obrigado á reparação.

Não chegaram, ainda assim os romanos a uma sistematização do seu direito civil; em todo o caso um grande passo de progresso haviam alcançado e os jurisconsultos se esforçavam por firmar: a responsabilidade com base na culpa, em lugar do princípio primitivo da causalidade material: sem culpa não havia responsabilidade - é o grande princípio clássico que nos transmitiram os romanos.

\section{"O DELITO DA CIVILIZAÇÃO"}

Se quizéssemos dar á éra em que vivêmos, -- da segunda metade do seculo passado ao primeiro quartel do presente - epigrafe, simbolo, ou representação material, escolheriamos a máquina (2).

Com a descoberta e aplicação do vapor e da eletricidade á indústria, a máquina assumiu uma importancia avassaladora na vida dos povos. Ao mesmo tempo criou-se a classe operaria: representava o trabalho, que tem por fim o desenvolvimento do capital. E os patrões, - pela repetição de uma lei que, parece, é fatal na vida dos povos, assumíram a posição de senhores. E os operarios tomaram o lugar dos servos. A' éra da agricultura sucedía a da indústria.

Logo se verificou que a máquina colocava o operario em situação de sofrer com grande freqüência, danos graves, senão irremediaveis. Se prevalecêsse nas legislações, o critério da culpa, critério classico e tradicional, - o operario vítima de um acidente, teria necessidade de provar a culpa por parte do patrão, afim de obter a indenização. $\mathrm{Na}$ 
maioria dos casos o operario, parte mais fraca, sería o sacrificado, já porque é dificilimo, e muitas vezes impossivel, fazer essa prova; já porque frequentemente $o$ acidente provém de caso fortuito, não tendo - quer o patrão, quer o operario - culpa alguma.

Reconhecendo a insuficiencia do critério da culpa, procurou-se substitui-lo por outro, mais geral, mais lógico, de maior justiça social :a teoria do risco, ou risco profissional. Cabe á França a primazía, pela promulgação, em 9 de Abril de 1898 , da celebre Lei de acidentes do trabalho, cujo artigo primeiro declára que os acidentes que sobrevenham a operarios e empregados, dão lugar a uma indenização paga pelo chefe da emprêsa.

Por estas palavras sintetiza Orlando a teoria do risco: "Todo aquele que, no exercicio de qualquer emprêsa ou atividade, lésa um direito de terceiro, deve reparar o prejuizo causado, mesmo que o dano não envolva, de sua parte, culpa ou negligência."

Lucien Arnette, aliás adversario da aplicação do princípio do risco á indenização, assim o define:

“Le risque professionel n'est autre chose que la responsabilité du fait des choses constiderées étroitement.

Si je subis les risques d'une profession qu'est ce à dire? Sinon que je cours les risques que me feront courrir directement où indirectement les “choses" multiples dont jai besoin pour exercer ma profession" (3).

Ninguem desconhece os esforços que têm feito nestes ultimos tempos, os jurisconsultos franceses no sentido de derivar dos textos do Codigo de Napoleão, o principio da responsabilidade objetiva e substituir como fundamento da responsabilidade, o fato de ser proprietario, ou o risco da propriedade, - á culpa ou negligência.

Daí a legislação, hoje universal denominada dos aciden- 
tes de trabalho, em que se consagrou outro principio, tambem de origem romana, ubi emolumentum, ibi onus, isto é: aquele que tira ou obtêm os proveitos, deve arcar com os percalços.

Não parou aí, não se limitou aos acidentes do trabalho, a aplicação da teoria do risco ou da culpa in ré. Cedo se constatou que, aplicada a máquina, e consagrada a indústria ao problema do transporte, - os meios de condução se haviam tornado um perigo comum.

$\mathrm{O}$ automovel é produto da indústria moderna. Tendose em vista a sua natureza especial, as suas qualidades mais apreciaveis, a grande velocidade que desenvolve, as circunstâncias em que ocorrem os acidentes, o seu número sempre crescente e a gravidade impressionante dos danos, a rapidez com que os acidentes se verificam, a situação das vítimas, a facilidade de fuga, trazendo como conseqüência a impunidade, - tudo patentêa que uma providência legislativa se impõe. Acrescente-se que as cidades não foram construidas, nem as ruas calçadas, nem as populações edurcadas - para tão intenso e perigoso trânsito. Ao tempo do nosso Codigo Penal, não existiam automoveis. Os seus primeiros comentadores dão como exemplo de imprudencia, o conduzir um carro de praça em disparada. Hoje os carros de tração animal dirigem-se rapidamente. para os museus.

"Delito dos tempos modernos", qualificou Tejerina (4) o delito culposo. Ao passo que Angiolini, uma das maiores autoridades na matéria, chamou-o "delito da civilização" (5). Enfim, os mais eminentes criminalistas salientanto, não só a gravidade dos crimes de imprudencia (impropriamente ditos culposos), como o seu aumento sempre constante depois do progresso dos meios mecanicos de locomoção, - dizem a uma vóz, que a defesa social necessita severas medidas afim de que essa fórma de criminalidade seja coibída. Não só dia a dia aumentam os desastres de automovel, como a imprudencia dos condutores é cada vez maior. A morte, principalmente de crianças e de velhos, vai num crescendo assustador.

"Quando o famoso Lagartixa, ao definir a arte de torear 
dizia: Tu te pones delante del toro, y éste arranca; si no te quitas de en medio, te quita el - parecia entrevêr a arte de circular nas grandes cidades" (6).

$O$ estudo do direito comparado justifica a legislação especial. Atualmente, em todos os paises há leis especiais sôbre automoveis; os condutores e proprietarios dêsses veículos não estão sujeitos ao direito comum, e sim a normas excecionais. O fato é eloqüentissimo: se os legisladores de quasi todos os povos cultos têm promulgado leis especiais, é porque verificaram levantarem-se razões muito graves exigindo a inovação; na doutrina, raros os escritores que as não assinalam.

Urge, pois, é absolutamente imprescindivel, que sejam tomadas medidas eficientes contra o aumento, cada dia maior, dos crimes culposos praticados pelos condutores de automovel.

As estatisticas são impressionantes. Ninguem põe em dúvida - e as taxas das companhias de seguros são a contraprova indiscutivel - que o automovel é veículo muito mais perigoso do que o aeroplano. Na Inglaterra uma companhia de seguros compilou a estatistica de acidentes mortais que se verificaram com os diferentes meios de transportes, aereos e terrestres, em relação ao numero de quilômetros percorridos :

108.000 ks. de estrada de ferro ou tramway;

$137.000 "$ " motocicleta;

$260.800 "$ " auto onibus;

$262.400 "$ " autos particulares;

$446.400 " \quad " \quad "$ publicos;

$560.000 "$ " aeroplanos de esporte e particulares;

$1.518 .400 ", "$ de linhas regulares;

Estatisticas analogas organizadas na Alemanha fornecem resultados idênticos (7). Nas linhas regulares e comerciais aereas da Alemanha não houve, no ano findo de 1933, um só desastre mortal!

Agora os automoveis: O Daily Chronicle escrevia, não 
ha muito: "De sabado a segunda-feira tivemos 32 mortos e 65 feridos: é o tributo minimo que temos de pagar todas as semanas, ao progresso."

$\mathrm{Na}$ Inglaterra se verificam anualmente 4.000 mortes e mais de 100.000 feridos por acidente de automovel. Em Nova York, só na cidade de Nova York, morreram em 1928 - 26.213 pessoas; foram feridas 998.700 , o que representa um aumento de 13 por cento sôbre a estatistica do ano anterior. Na Espanha, no mesmo ano, com um total de automoveis infinitamente inferior, o número de acidentes foi de 11.200 , com 3.200 mortes. Nas ruas de Londres, em 1929, morreram atropeladas, nada menos de 1.362 pessoas. No ultimo trimestre do dito ano registraram-se 407 mortes e $\mathbf{1 4 . 1 1 1}$ ferimentos. Equivale a dizer que durante os meses de outubro, novembro e dezembro quatro pessôas por dia saíram de casa para não voltar. E foram particulares os veiculos que maior número de desastre causaram. Ainda na Inglaterra, em 1931, passou de 6.000 o numero de acidentes com lesões corporais. O Departamento do Comencio de Nova York publicou a estatistica de 1931: 8.528 mortos. O número de vítimas aumentou de 20 por cento sobre o ano anterior. Ainda assim, comparativamente ao numero de automoveis, Nova York está, quanto aos acidentes, em posição muito melhor do que a Europa, de vez que alí circulam 25 milhões de automoveis, ou seja um para cada cinco habitantes. (8).

A revista paulista Idort, em seu numero de Março de 1932, publicou um interessantissimo trabalho do Dr. Roberto Mange, intitulado "A zona de perigo dos automoveis", no qual demonstra, irretorquivelmente, que o perigo do automovel está na razão diréta da velocidade. Confirmando a tése do Dr. Roberto Mange, verificou-se nos Estados Unidos que em 90 por cento dos desastres a causa foi o excesso de velocidade. 


\section{UM PROJETO ESQUECIDO}

Foram, sem duvida, considerações desta ordem, que levaram á apresentação do projéto que adaptava ás condições do momento nossa legislação.

Duma parte atendia-se ao direito civil aceitando a culpa in ré, ou a responsabilidade objetiva.

Doutra parte acudia-se aos reclamos do aspecto penalsocial, agravando as penas, distinguindo entre os ferimentos leves e graves, e inovando, ainda, pela criação de circunstâncias agravantes e atenuantes.

Por ser pouco conhecido, damo-lo na integra:

“Art. 1. --- Ninguem poderá exercer a profissão de condutor de veiculos automoveis, sem satisfazer préviamente as condições de idade, moralidade e capacidade têcnica e física que foram determinadas nas posturas municipais do lugar.

$10^{\circ}$ - Aos que tiverem satisfeito tais condições será concedida pela autoridade municipal a licença para a condução dos mencionados veículos, e o respectivo certificado deverá ser exibido pelo condutor, sempre que a autoridade policial o exigir.

$2 .^{\circ}$ - Aquele que fôr encontrado em ato de conduzir um veículo automovel sem ter obtido a necessaria licença, será punido com a pena de multa de $50 \$$ a $500 \$$, conversivel em prisão celular, na forma do art. 59 do Codigo Penal.

$3 .^{\circ}$ - Os proprietarios de automoveis e os gerentes de empresas ou sociedades destinadas á exploração da indústria de transporte de pessoas ou de carga de qualquer especie, que empregarem cientemente algum condutor não habilitado na forma do parag. $1 .{ }^{\circ}$, incorrem na pena de multa de $100 \$$ a $1: 000 \$$, conversivel em prisão celular, na forma do citado art. 59 do Codigo Penal.

$4 .^{\circ}$ - Entendem-se por automoveis os carros e veículos movidos por máquinas, sem serem ligados a trilhos.

Art. $20^{\circ}-\mathrm{Em}$ quaisquer regulamentos ou posturas para o fim de regular a circulação dos automoveis, a velocidade 
dos veículos, quer oficiais, quer particulares, quer de uso publico, será marcada de modo a não exceder de 20 kilometros por hora nos lugares de maior movimento, nos centros urbanos, nem de 40 kilometros em campo aberto.

$10^{\circ}$ - Dentro dos limites acima a velocidade dos veículos automoveis será regulada pelas posturas municipais, devendo ser moderada conforme as circunstâncias.

$2 .^{\circ}$ - $\mathrm{O}$ excesso de velocidade constituirá contravenção punivel com a pena de $40 \$$ a $120 \$$, conversivel em prisão celular, na forma do já citado art. 59 do Codigo Penal, independente de qualquer acidente que desse excesso tenha resultado.

$3 .^{\circ}$ - A contravenção de que trata o parágrafo anterior se verificará e comprovará por aparelho que se adapte a tal fim, ou, na falta dêste, pela simples intimação da autoridade competente aos condutores.

Art. $3 .^{\circ}-\mathrm{O}$ condutor de qualquer veículo automovel que, por imprudencia, negligência ou imperícia, ou por inobservancia de alguma disposição regulamentar, cometer, ou fôr causa involuntaria, direta ou indiretamente, de alguma lesão corporal, será punido com as seguintes penas de prisão celular:

a) — de 16 a 60 dias, se a lesão corporal produzir somente dôr, sem outras conseqüências, sem derramamento de sangue;

b) - de dous a seis meses, se produzir incomodo de saude que inhabilite o paciente de serviço ativo por mais de 30 dias;

c) - de dois a quatro anos, se da lesão corporal resultar imutilação ou amputação, deformidade ou privação permanente do uso de um órgão ou membro, ou qualquer enfermidade incuravel e que prive para sempre o ofendido de poder exercer o seu trabalho;

d) — de tres a seis anos, se da lesão corporal resultar a morte do ofendido.

Art. ${ }^{\circ} .^{\circ}$ - A fiança não será concedida ao condutor que, tendo cometido ou sido causa involuntaria de alguns 
dos fatos previstos nas letras $a$ e $b$ do artigo anterior, não se detiver imediatamente, mas fugir, procurando escapar á nesponsabilidade penal ou civil em que possa ter incorrido.

Nesses mesmos casos, porém, a fiança será concedida ao condutor que não houver ficado no lugar do acidente, si dentro de 24 horas êle provar cumpridamente que a sua permanencia naquele local o expunha a perigo iminente, motivado pela reação da propria vitima, ou pelos impulsos de terceiros, contra êle condutor.

$10^{\circ}$ - Nos casos de que trata a disposição antecedente, primeira parte, a parada imediata do veículo automovel e a declaração do acidente, feita, logo ou dentro do praso de 24 horas, á autoridade policial competente e mais proxima, tornam afiançaveis os delitos previstos nas mencionadas letras $a$ e $b$ do art. $3 .^{\circ}$ e serão considerados como circunstancias atenuantes da responsabilidade do réo.

$2 .^{\circ}$ - O proprietario, locatario ou ocupante qualquer de um veiculo automovel que tenha ocasionado um acidiente é obrigado a fazer a respectiva declaração, dentro de 24 horas, á autoridade policial mais proxima do local do acidente ou da casa ou estabelecimento a que pertencer o veículo, sob pena de multa de $100 \$ 000$ a $500 \$ 000$.

Art. 5. - Quando nos casos de acidente de qualquer veículo, tres ou quatro testemunhas oculares certificarem, peremptóriamente e sem contestação, que o condutor nenhuma culpa teve - a ordem de prisão em flagrantle será relaxada, ou o respectivo auto não se lavrará.

Art. 6..$^{\circ}$ - Todo acidente de que resultar dano material, ocasionado por qualquer fato de veículo automovel em circulação na via publica, dá logar, em proveito da vitima ou de seus representantes legais, a uma indenização do prejuiso causado.

$1 .^{\circ}$ - Ésta indenização incumbe ao proprietario do veículo, que só poderá declinar da responsabilidade civil e subtrair-se ao pagamento provando algum dos fatos seguintes: 
a) - que o acidente ou dano foi provocado ou agravado por culpa grave da vitima;

b) - que o automovel era conduzido ou manejado, no momento do acidente, pela propria vitima, ou preposto desta;

c) - que o automovel tinha sido posto em circulação por terceiro, sem ciência ou conhecimento do proprietario.

$2 .^{\circ}$ - $O$ terceiro que se servir do automovel sem ciência ou conhecimento do proprietario, é responsavel pelo dano causado, como se fôra proprietario.

$3 .^{\circ}$ - Aquele a quem o proprietario concedeu o gôso de automovel, para fazê-lo circular por sua conta, mediante pagamento ou não, responderá pelo dano como si o proprietario fôra, no caso em que, pelo tempo e condições do contrato ou concessão, o possuidor ou detentor tenha o direito de escolher o condutor, ou em que tenha entregue o automovel para ser conduzido por um condutor, que não seja preposto ou empregado do proprietario.

$4 .^{\circ}$ - Nos acidentes ocasionados por automovel posto permanentemente ao serviço dos funcionarios ou autoridades que, por sua categoria, tiverem direito a tal condução por conta dos cofres publicos - a indenização do dano incumbe ao funcionario ou autoridade a cujo serviço permanente estiver o automovel, ou sob cuja responsabilidade o mesmo circular.

Art. $7 .^{\circ}$ - $\mathrm{O}$ caso de força maior exclúe a responsabilidade criminal do condutor, mas não se considera como tal o acontecimento advindo de um defeito de construção do automovel ou da fratura ou desarranjo de qualquer peça, nem de outra qualquer causa imprevista, peculiar ao uso dos veículos de motor mecanico.

Art. 8. $^{\circ}$ - No Distrito Federal, as contravenções definidas na presente lei serão processadas e julgadas de conformidade com o art. $6 .^{\circ}$ da lei $n:^{\circ} 628$, de 28 de outubro de 1899, com apelação para a Câmara Criminal da Côrte d’e Apelação. 
$10^{\circ}$ - Os delitos de que trata o art. $3 .^{\circ}$ letras $a$ e $b$, serão processados e julgados pelos pretores criminais, na forma do art. 262 e seus parágrafos do decreto n. 9.263 , de 28 de dezembro de 1911.

$2 .^{\circ}$ - Os delitos de que trata o citado art. $3 .^{\circ}$, letras $a$ e $d$, serão processados e julgados pelos juizes de direito do crime, na forma dos arts. 265 e 266 do mencionado decreto n. $^{\circ}$ 9.263, de 1911.

Art. 9. - Em caso de infração desta lei ou de quaisquer regulamentos e posturas aplicaveis em materias. de circulação por veículos automoveis, o culpado, além das demais penas, será privado do direito de conduzir qualquer automovel durante um praso de dez dias a tres meses, e, neste caso, a respectiva licença e certificado de capacidade ficarão depositados na repartição de policia de veículos, durante o praso da interdição.

$1 .^{\circ}$ - No caso de reincidencia em qualquer dos crimes previstos no art. $3 .^{\circ}$ letras $c$ e $d$, da presente lei, isto é, em caso de condenação do réo, será o mesmo privado definitivamente de exercer a profissão de condutor de automovel.

$2 .^{\circ}-\mathrm{O}$ condutor será privado definitivamente da. licença de conduzir, se, por sentença passada em julgado, fôr ou houver sido condenado ás penas dos crimes de roubo ou furto, lenocinio, homicidio, rapto, violencia carnal, subtração de menores, estelionato, ou no caso de reincidencia por embriaguez ou por qualquer dos crimes previstos no art. $3 .^{\circ}$, letras $c$ e $d$ da presente lei.

3. - A licença de conduzir o certificado de capacidade, cassados pela autoridade competente, na forma prescrita no parágrafo anterior.

Art. 10 - Se não houver notificação legal do dano, ao responsavel dentro de um mês, a partir do acidente, o interessado perderá o direito á indenização.

Art. 11 - A ação para haver a indenização do prejuizo resultante de qualquer acidente ocasionado por automovel em circulação na via publica prescreve em dois anos, a partir do dia em que teve lugar o fato. 
Art. 12 - Em caso de colisão de automoveis, a obrigação de indenizar será regulada pelo direito comum, segundo as circunstâncias.

Art. 13 - Apresente lei entrará em execução logo depois de publicado o respectivo regulamento, que deverá ser expedido dentro do prazo de tres meses, a contar da promulgação desta.

Art. 14 - Revogam-se as disposições em contrário"

Apresentado em 1915 na Câmara dos Deputados, venceu as tres discussões e em 1917 chegou ao Senado. No Senado o projeto arrastou-se com lentidão que desmentia o seu conteúdo: não parecia tratar-se de uma lei sôbre automoveis. $\quad$ Em 1919 ainda se achava em segunda discussão. Recebeu emendas em conseqüência das quais deveria voltar para a Câmara; interveiu, ou melhor predominou a politica, e o projeto foi esquecido.

Não deixemos a vaza sem prestar homenagem ao representante de S. Paulo no Senado Federal, o eminente jurista Adolfo Gordo, que tão ardorosamente e brilhantemente se bateu pelo projeto, e que, desgraçadamente, _ por uma dessas ironias do destino - faleceu vitimado pela imprudencia de um motorista apressado.

A trágica morte do senador Adolfo Gondo devia ter sido incentivo a que o projeto tivesse andamento.

Entretanto, permaneceu na pasta dos papeis mortos.

Enquanto isso ocorria no Brasil, a Suissa, só porque demorou-se em alcançar as demais nações européias no legislar sôbre acidentes originados de transporte, foi qualificada de "oasis de barbárie em meio da civilização"

No particular do fundamento da responsabilidade, a evolução de nosso direito apresenta aspectos que merecem rememorados. Filiado nosso direito, á teoria classica da culpa, cabia á vitima (sujeito passivo do ato ilicito) o onus da prova de imprudencia ou negligência, - culpa, enfim - por parte do autor do dano.

Em 1912 foi promulgada a chamada lei das estradas de ferro, n. ${ }^{\circ} 2681$, que abria uma nova fase ao nosso direito. 
A segunda parte do art. 1. $0^{\circ}$ dispõe: "Será sempre presumida a culpa e contra ésta presunção só se admitirá alguma das seguintes provas:

$10^{\circ}$ ) - "caso fortuito ou força maior" etc. A lei prevê mais seis hipóteses, mas declara no art. 2. ${ }^{\circ}$ " $S e$ nos casos dos ns. 2, 3, 4, 5, 6 e 7 do artigo anterior concorrer culpa da estrada de ferro com a do remetente ou destinatario, será proporcionalmente dividida a responsabilidade"

$\mathrm{O}$ art. 17 contém disposições da maior importancia: “As estradas de ferro responderão pelos desastres que nas suas linhas sucederem aos viajantes e de que resulte a morte, ferimento, ou lesões corporais.

“A culpa será sempre presumida, só se admitindo em contrário alguma das provas seguintes:

1..$^{\circ}$ caso fortuito ou força maior;

2..$^{\circ}$ culpa do viajante, não concorrendo culpa da estrada"

Art. 22. - No caso de morte, a estrada de ferro responderá por todas as despesas e indenizações á arbitrio do juiz, a todos aqueles aos quais a morte do viajante privou de alimento, auxilio e educação"

Depois veiu do Codigo Civil. Se não era de esperar que o legislador abraçasse a teoria do risco, parecia certo que, pelo menos, seguiría a trilha já calcada da presunção da culpa. Tudo o fazia esperar.

O projeto Clovis e o projeto da Câmara declaravam respectivamente: "Céssa a responsabilidade das pessoas mencionadas. etc. provando-se etc. O projeto da Câmara era ainda mais positivo: "Não serão responsaveis as pessoas de que tratam os dois arts. antecedentes. provando-se. etc.

Andrade Figueira criticou com toda procedencia o atual art. 1.523 demonstrando que, na generalidade em que se acha formulado, anula a responsabilidade das pessoas mencionadas no art. 1.521, ou sejam os pais, tutores, curadores, patrões, mestres, etc. "Éstas justas considerações, observa JoÃ̃o LuIz Alves, ficaram sem resposta" (9). 
Dado o desenvolvimento industrial em diversos pontos do país, a situação, especialmente em relação aos operarios, tornava-se insuportavel. Posterior ao Codigo Civil, para dar-lhe remédio veiu a lei dos "Acidentes de Trabalho" cujo fundamento é: ubi emolumentum, ibi onus, isto é, aquele que tira as vantagens, deve arcar tambem com os onus. A unica hipótese pela qual fica excluida a responsabilidade do patrão, é a de dólo por parte do operario.

De grande interêsse $\mathrm{e}$ não menor proveito apreciar e responder as criticas que surgíram contra o "Projeto esquecido" Fa-lo-êmos muito pela flor.

Foi êle decalcado no projeto organizado pela "Société d'études legislatives", de Paris, que teve por principal redator o notavel jurista Ambroise Colin.

Arthur Lemos num largo e erudito voto em separado, que se encontra nas publicações do Senado da Republica, n..$^{\circ}$ 470, de 1917, examina com grande elevação a materia. Nesse trabalho colhêmos algumas das notas do presente ensaio.

Nos termos em que foi redigido, o projeto não atendia á força maior, isto é, ainda nesse caso o proprietario do veículo seria responsavel. Este ponto foi muito discutido no Senado, sendo aceita a emenda do Senador Rego Monteiro e acrescentadas á letra $a$ do parágrafo primeiro do art. 6 as seguintes palavras: "que o acidente ou dano resultou de força maior"

Aplicada a teoria do risco com todo o seu rigôr, o proprietario de um automovel é responsavel pela indenização do dano resultante de um acidente, mesmo nos casos de força maior. E porque? Porque essa responsabilidade decorre - não de qualquer culpa sua ou do condutor, mas "do risco que aquele veículo criou", de modo que os casos fortuitos ou de força maior não podem exonerá-lo. Diz Alberto WaHL, e diz bem: "Les cas fortuits ou la force majeure s'opposant à la faute, ils doivent rester étrangers aux hypothèses où la responsabilité ne dérive pas de la faute. 
C'est en ce sens, et très justement que s'est prononcéel la commission de la Société d'Études législatives"

Entretanto o mesmo Alberto Whal nos informa que Ambrorse Colin ao relatar o projéto organizado pela Société d'Études législatives perante a Câmara dos Deputados de França aceitou a emenda modificadora do projeto, no sentido de isentar o proprietario do auto de responsabilidade civil no caso de fôrça maior. (10).

Nossa Camara alta seguía o exemplo do corpo legislativo francês, notando-se que em França (como aliás em quasi toda a Europa) as questões de indenização são frequentissimas, e de excecional importancia. Aliás, o Congresso incluindo a fôrça maior entre as excusas, colocava a lei sôbre automoveis am harmonia com a lei das Estradas de Ferro, como já vimos.

Lucien Arnette (11) admite a responsabilidade objetiva na esfera das relações entre patrão e operario; impugna-a, porém, como excessiva, no terreno do projeto, por sua ampliação á humanidade inteira. Os partidarios dessa extenção (observa, e com certa procedencia) a-pesar-de ávidos de uma justiça maior, não fazem senão deslocar a injustiça. "Le propriélaire d'une chose en jouit, il en retire une utilité, un agrément, il doit en subir les conséquences. Il doit en assumer les risques, tous les risques. Ceci est d'une' logique parfaite, mais d'une logique monstrueuse. Son application pratique ne tendrait rien moins qu'à faire retourner le monde à la barbarie primitive. Voilá un homme d'une fortune moyenne, d'une intelligence et d'une activité moyennes, de besoins moyens. Combien peut-il posséder de choses? mot si vaste, si pressant dans sa petitesse. Et pour chacune de ses choses, $\dot{a}$ chaque instant, chaque seconde, dans quelque lieu où il se trouvera, il pourra être inquieté, tourmenté, ruiné peut-être, sans que sa prevoyance, sa reflexion prudente aient pu l'empêcher. Parce que "malgré lui, sa chose" a nui à quelqu'un. Et dire que le rêve de tout homme est à present de "posséder" quelque chose, beaucoup de choses, d'être propriétaire! Autant dès lors avoir l'épée de Damocles suspendue sur sa tête!" 
A voz de Lucien Arnette era a da razão, e tendia a abrandar os excessos nascidos da primeira reação. De fato: em França quando começou a refletir na jurisprudencia a reação contra a frequencia e impunidade dos acidientes de automovel, houve tais exageros, que não faltou quem considerasse tais veículos como verdadeiros flagelos.

"Les chauffeurs? On devrait les condamner sans les juger!" exclamou em plena audiencia o juiz de paz de Beauvais. (12).

Um juiz norte-americano, referindo-se aos delinqüentes por imprudencia, empregou adjetivos tão violentos, que não era de esperar proferidos por quem devia, por seu cargo e dignidade, medir e pesar mais as palavras. Gabava-se de haver, num só dia, imposto oitenta multas, num total que só pode ser atingido na patria dos exagêros: 2.010 dolars. "Nas cidades, dizia o mesmo magistrado, House, ninguem tem o direito de ter pressa, si ésta puder ocasionar violação do direito primordial dos cidadãos, isto é, o direito á vida. Não aceito excusa, nem pretexto. Condenei hoje um que ia buscar açucar e outro que procurava um remédio para a mãe enferma. Ambos haviam delinquido pela primeira vez. Sim, não posso vêr, em quem leva um automovel a toda velocidade por uma rua transitada, qualquer que seja o motivo, - senão um homem com instintos homicidas, para quem a existencia dos demais não meréce sacrificio algum. Isto é: POTENCIALMENTE UM ASSASSINO. Se voltarem aqui, nunca mais poderão tomar a direção de um automovel" (13).

Isto não se comenta em materia de direito penal. No terreno da responsabilidade civil, a teoria do risco levada a suas extremas conseqüências, importaria quasi na mesma solução para os proprietarios de automovel, desde que não ouve a êstes senão no que diz respeito o fato, ou seja a constatação do nexo de causa a efeito entre os veículos e os danos causados a terceiros.

Na Italia o Codigo das estradas (R. d. Dezembro de 1928, convertido em lei em 17 de Março de 1930, n. 230 ) 
estabelece que "o dano produzido em pessôas ou cousas pela circulação do veiculo se presume devido á culpa do condutor"; mas acrescenta: "a presunção é excluida quando êste (condutor) prove que de sua parte houve toda diligência em evitar que o dano se verificasse" Desta feita a primazia cabe á Inglaterra, cujo Motor-car-act traz a data de 14 de Agosto de 1903, ou seja da época em que começou a interessar o problema da circulação. A lei dinamarquesa de 30 de Agosto de 1906 foi a primeira a atender aos que se levantaram contra o onus da prova imposto á vitima, em materia de acidentes de automovel; segundo seus dispositivos, a obrigação da indenização cumpre ao proprietario ou a quem utiliza o veiculo; é ilidida pela circunstancia de negligência ou falta intencional da vitima, ou pela inevitabilidade do prejuiso.

Igualmente é presumida a culpa do proprietario, na Alemanha, desde 1909; na Austria, desde 1908; na Belgica, o projéto provocou acaloradas discussões. Foi reconhecida a circunstância da fôrça maior; no caso fortuito, fato independente da vontade, não se incluiu a hipótese do acidente provir de um defeito ignorado do automovel. Essa idéia já havia sido, em 1907, abraçada na Suissa por MeIlr, o conhecido professor de Berne.

As leis mais modernas são a italiana, já citada; a espanhola, de 13 de Julho de 1926; e a lei federal suissa, que traz a data de 15 de Março de 1932. Ésta, segundo a opinião abalisada de Colon y Marimón, “é um verdadeiro modelo quanto á previsão dos possiveis casos, e ás normas mais justas para a solução de cada um deles" (14). No artigo 37 se lê: "se em conseqüência do emprêgo de veiculo automovel resultar a morte ou ferimento em qualquer pessôa, ou fôr causado qualquer dano, - o dono do veiculo será civilmente responsavel. Ficará liberado da responsabilidade civil quando provar que o dano foi devido a fôrça maior, ou culpa grave do prejudicado ou de terceiro, sem que nem êle, nem as pessôas por quem seja responsavel, haja cometido qualquer falta. Se a falta imputavel ao prejudicado ou a 
terceiro fôr leve, o juiz fixará a indenização exigivel ao dono, tendo em conta todas as circunstâncias do caso" $O$ rigôr não pode ser maior. $O$ proprietario do carro para se livrar da responsabilidade, deverá provar o caso fortuito, ou a falta grave do prejudicado; mas a rigidez do dispositivo é temperada a criterio do juiz, a quem a lei concéde grande liberdade.

$\mathrm{Na}$ Inglaterra distingue-se entre os automoveis utilizados para fins industriais, e os outros; os automobilistas, neste último caso, podem invocar não só a fôrça maior, como o caso fortuito; no primeiro caso, isto é, de automoveis empregados para fins industriais, só póde o automobilista invocar a fôrça maior, isto é, o "ato de Deus", a catástrofe natural, raio, tempestade, inundação ou terremoto. Verdade é que o direito britânico se funda na idéia tradicional da culpa, e não na moderna teoria do risco. Mas o rigôr é tal, que os resultados praticos são os mesmos.

Em França, onde a teoria do risco teve tão entusiasmados propugnadores, a jurisprudencia deu ás velhas disposições do Codigo napoleonico interpretação elastica, especialmente quanto ao fato das coisas, de que trata o art. 1.384 do Codigo Civil. Foi, na Camara dos Deputados, apresentado um projeto pelos senhores Besnard e DaNThié, porém logo rejeitado como perturbador da harmonia do velho Codigo Civil. O segundo, resultado das discussões da Société d'Etudes législatives, é claro, logico e preciso; nele colaboraram especialmente, além de Ambroise Colrn, Thaller e Querent. Nele se ímspirou o autor do projeto que faz objeto deste ensaio.

\section{CRITICA DO PROJETO}

$\mathrm{E}$ ' tempo de estudar as inovações de caráter penal contidas no Projeto esquecido.

São várias e de vária natureza. Temos, em primeiro lugar, as contravenções criadas e as respectivas penas. Entre estas, parece-nos de maior importancia a do parag. $3 .^{\circ}$ do 
art. $1 .^{\circ}$ que prevê a multa de $100 \$ 000$ a $1: 000 \$ 000$, conversivel em prisão, nos termos do art. 59 do Codigo Penal, aplicavel aos proprietarios de automoveis, e gerentes de empresas, etc., que empregarem seus veículos a condutores não habilitados. Como medida preventiva, é de grande alcance.

O excesso de velocidade passa a contravenção; a pena de multa oferece resultados praticos; parece-nos, todavia, muito pouco: $40 \$ 000$ a $120 \$ 000$.

$\mathrm{O}$ art. $3 .^{\circ}$ merece aplauso quanto a seus incisos; merece reparo quanto ao corpo. E' a reprodução quasi ipsis literis do Codigo Penal. Que o projeto não adotasse a teoria do risco em materia penal, transeat; mas, ao menos declarasse que o onus da prova da inocencia cumpre ao autor do acidente, presunção de culpa.

Os incisos do art. $3 .^{\circ}$ têm em vista o dano causado pelo acidente e por êle gradúam a pena. De fato: é injusto o regime atual do Codigo Penal: uma lesão corporal gravissima, irremediavel, que inutiliza para sempre a vitima, é punida com a mesma pena que um leve arranhão ou simples dôr, sem derramamento de sangue. O projeto prevê a lesão corporal leve, a lesão corporal grave, sob o criterio economico, da privação de serviço ativo por mais de trinta dias; a lesão corporal de que resulte mutilação, amputação, deformidade ou privação permanente de uso de membro ou órgão; e finalmente eléva de tres a seis anos o minimo e o maximo no caso de morte. Pelo Codigo Penal o minimo do art. 297 é de dois meses e o maximo de dois anos, o que é simplesmente irrisorio!

$\mathrm{O}$ art. 4 é dedicado á fiança e á fuga. Em quasi todos os paises europeus, verfiicada a impunidade de cerca de $90 \%$ dos desastres de automovel entre outras razões, pela facilidade da fuga, - foi esta considerada um delito, e criado o delito da fuga. Se o acusado provar fôrça maior, caso fortuito, culpa exclusiva da vitima, etc. será absolvido pelo desastre, mas responderá pelo delito da fuga. Nosso legislador não teve animo de ir tão longe: propôs uma 
combinação entre a fuga e a fiança. $O$ autor do desastre não teria direito á fiança se não se tivesse detido no local, mas fugisse, procurando escapar á responsabilidade penal e civil. A paráda imediata do veiculo e a declaração do acidente ás autoridades, competentes, seríam consideradas como circunstância atenuante.

Ao art. 11 relativo a prescrição da ação para haver a indenização do prejuiso resultante de acidente de automovel, prescrição que é fixada em dois anos a partir do dia em que teve lugar o fato, - propôs Arthur Lemos o seguinte aditamento, inspirado na lei alemã e aceito pela comissão:

"Caso as duas partes entrem em negociações com o intuito de liquidarem amigavelmente a indenização, a prescrição ficará suspensa até que uma delas se recuse a continua-las"

Disposição que merece louvada e completa a anterior relativa á prescrição.

Como dissémos, o projeto jaz á espera de quem o ressuscite; assim, parece-nos que não é mal se apontem algumas das lacunas que observámos.

Por exemplo: o artigo 12: “em caso de colisão de automoveis, a obrigação de indenizar será regulada pelo direito comun, segundo as circunstâncias" Este artigo é perfeitamente inutil: não inóva, nem esclaréce. Mais oportuno, e de caráter penal é o art. 113 do Codigo Penal italiano: no delito culposo, quando o evento resultar da cooperação de mais de uma pessôa, cada uma delas responderá pelo seu proprio delito"

Gostariamos de vêr no texto da lei um artigo que correspondêsse ao artigo 44 da lei espanhola, subordinado ao titulo das velocidades:

“A velocidade dos veículos automoveis deverá ser tal que seus condutores possam cumprir a todo instante, sem incerteza e com facilidade, a totalidade das prescrições dêste Regulamento" Em poucas palavras, com clareza e segurança, está traçada a medida da prudencia.

Outro ponto que o projeto devia resolver é o seguinte: 
De acôrdo com o Codigo Penal, quando, pelo mesmo acidente resultarem lesões ou morte de diversas vitimas, — qual a situação do réu? Deve responder por tantas vezes quantas forem as vitimas? Ou uma só vez incurso no artigo 306 ou 297? Deve-se considerar mais de um crime o fato de haver mais de uma vitima?

Parece-nos que não. A definição de crime que se encontra no Codigo Penal tem sentido exclusivamente subjetivo, atende á unidade ou pluralidade das ações que infringem a lei penal; não há a preocupação da extensão do dano quanto ao número das vitimas.

No artigo 66, que regula a aplicação das penas, devería se encontrar a solução para a dúvida; mas não se encontra, como passamos a demonstrar:

Art. 66. - Na aplicação das penas serão observadas as seguintes regras:

$\S 1 .^{\circ}$ - Quando o criminoso tiver de ser punido por mais de um crime, impôr-se-lhe-ão as penas estabelecidas para cada um deles"

Não é a hipótese, porque, é claro que se o criminoso tiver praticado diversos desastres, isto é, diversas infrações do Codigo Penal, deverá responder de cada uma delas, independentemente do número de vitimas. $O$ que o Codigo prevê neste paragrafo é a pluralidadie de ações em desobediencia á lei penal.

O parágrafo $2 .^{\circ}$ destinava-se a definir o crime continuado. Devido á pessima redação, deu lugar a dúvidas e discussões, e afinal foi substituido pelo artigo 39 do D'ec. 4.780 de 27 de Dezembro de 1923, ficando redigido nestes termos:

"Quando o criminoso tiver de ser punido por dois ou mais crimes da mesma natureza, resultantes de uma só resolução contra a mesma ou diversa pessôa, embora cometidos em tempos diferentes, se lhe imporá a pena de um só dos crimes, mas com aumento da sexta parte".

Tambem não se aplica. E não se aplica porque fala em "dois ou mais crimes", e uma só infração da lei penal 
constitúe um só crime, embora dele resultem diversas vitimas. Não se aplica, ainda, e principalmente porque alude a "dois ou mais crimes da mesma natureza, resultantes de uma só resolução, contra a mesma ou diversa pessôa. etc.

Ora: resolução é deliberação, é proposito, é decisão, é determinação, - o que tudo importa em vontade, portanto em dolo, e nós tratamos de crimes culposos. Há vontade no ato que constitúe o crime culposo, o ato é voluntario; as suas conseqüências é que são contrárias ou exorbitam da vontade.

E, se alguma dúvida pudesse subsistir, aí está a preposição contra colocada em seguida a resolução, para indicar o sentido de oposição: os crimes se praticam contra alguem que é a vitima, a mesma ou diversa pessôa, segundo as expressões no Codigo. E' pois evidente que o legislador se referiu a crimes dolosos, no parag. $20^{\circ}$ do art. 66 , modificado posteriormente.

O parag. $3 .^{\circ}$ do mesmo art. 66 , tambem se refére a crime doloso; é clarissimo: "Quando o criminoso, pelo mesmo fato e COM UMA SO' INTENÇÃO, etc. .

A nosso vêr, perante o Codigo Penal, não importa o número de vitimas para a aplicação das penas previstas pelos artigos 306 e 297; importa o número de infrações. Se, pelo mesmo ato imprudente o réu feriu e produziu morte, deve ser processado como incurso uma unica vez no art. 297 que, sendo mais grave, absorve o outro. Considera-lo incurso tantas vezes no art. 297 e tantas no art. 306 quantas forem as vitimas de morte e de ferimento, - é, parece-nos, perante o Codigo Penal, errado. Nosso Codigo Penal não considerou especialmente o caso de pluralidade de resultados de uma ação culposa, como influindo na configuração do delito e na penalidade, por isso que a disposição do art. 66 n. ${ }^{\circ} 3$ só é aplicavel em caso de crime doloso, embora tenha havido multiplo efeito lesivo da integridade fisica, com ou sem morte, advindo de uma só ação culposa, de uin só crime. (15). 
Neste sentido a decisão da Côrte de Apelação de 29 de Maio de 1920.

Vamos além, e no particular absolvêmos o autor do Codigo penal da Republica por esta aparente lacuna ou defeito. Parece-nos que pode ter sido intencional que o legislador considerasse subjetivamente a infração dos artigos 306 e 297, sem atender ao número de vítimas. Foi lógico, até, uma vez que não atendeu á gravidade das lesões para graduar a pena. Ainda mais, - e principalmente: Em 1890 os crimes de imprudencia eram rarissimos, ocasionando danos de importancia secundaria. Era no tempo da tração animal. Não urgia a necessidade de repressão; os meios de transporte não representavam, como hoje, um perigo comun.

Portanto, o que parece lacuna no art. 66 do Codigo Penal, é, (em nossa opinião), proposital.

O projeto Sá Pereira tambem não prevê a hipótese.

O Codigo Penal Italiano, entretanto, já a previa, no art. 371; e o atual o faz no art. 589 nestes termos:

"Aquele que, por culpa, ocasionar a morte de um homem, é punido com a pena de reclusão por seis meses a um ano.

"No caso de morte de mais de uma pessoa, ou de morte de uma e lesões pessoais de uma ou mais pessôas, aplica-se a disposição da primeira parte do art. 81; mas a pena acumulada não pode superar doze anos"

\section{CONCLUSÃO}

Si poderosas razões tornavam necessaria, há vinte anos. a promulgação das disposições de direito contidas no Projeto esquecido, multiplicadas e acrescidas elas assistem hoje. $\mathrm{O}$ número de automoveis aumentou extraordinariámente, $\mathrm{e}$ em conseqüência o número de desastres e o perigo público.

Não bastasse o estudo da legislação comparada, sobraria como imperiosa razão para uma lei nos moldes do projeto que estudámos, o espirito de logica que deve reinar no sistema juridico da nação. Pois, não é logico que para as estradas 
de ferro, em que o risco é menor mais reduzido o número de acidentes, inferior em extensão e gravidade o dano causado, - seja presumida a culpa da companhia, responda ela, em regra, "por todas as despesas e indenizações, a arbitrio do juiz, a todos aqueles aos quais a morte do viajante privar de alimento, auxilio ou educação", - ao passo que os autores de desastres de automoveis, muito mais numerosos, de danos muito mais extensos e graves, só respondam quando a vitima ou seus herdeiros conseguirem provar a culpa do autor e ainda assim, pela mesquinhez do Codigo Civil (art. 1537) a indenização só deverá consistir nas despesas de tratamento, funeral e luto da familia, e na prestação de alimentos a quem o defunto os devia.

Adolfo Gondo, o malogrado senador por S. Paulo, já assinalava em um de seus discursos que os tramways e os caminhos de ferro não devem estar sujeitos á imesma lei que os automoveis.

"Les accidents dus aux chemins de fer et aux tramways, ne méritent pas l'attention du législateur. Loin de faire naître un risque particulier, les chemins de fer et tramways diminuent le risque normal, puisqu'ils circulent sur les voies tracées à l'avance et où le public est coupable de s'engager inconsidérément ou de laisser s'engager sans précautions les animaux qui lui apartiennent" Quem assim se exprime é Albert WaHL, indiscutivelmente autoridade na materia. (16).

Inexplicavelmente, abrímos exceção no sistema juridico, para o meio de transporte que oferéce menos perigos; deixando os automoveis sujeitos ao império da lei comun, de um Codigo Penal, feito no tempo em que os automoveis não existiam, e um Codigo Civil em que o fundamento da responsabilidade é a culpa e o onus da prova incumbe á vitima.

"Considerando que na civilização moderna, racionalmente, dia a dia encontra maior justificação a responsabilidade civil fundada na causalidade objetiva e que, nesse sentido se encontra, nas legislações, uma acentuada tendência. " (17). 
Seja a conclusão desta tese o augúrio de que, dentro em breve o Brasil se colóque ao lado das nações que legislaram especialmente sôbre automoveis realizando o "projeto esquecido", ou promulgando lei em moldes idênticos; assim o exigem a justiça social, a lógica e a harmonia da lei.

S. Paulo, Junho de 1933.

\section{NOT A S}

(I) Fr., pr. e $\& 10^{\circ}$, D., IX, Ad Legem Aquiliam.

(2) Bertrand Russel, em sua magnifica obra "El panorama cientifico" (trad. do inglez de G. Sans Huelin, Madrid, 1931), diz que a éra em que vivemos é, por unanime consenso, a da ciência; o que, entretanto, não contraria a representação material que propômos.

(3) La responsabilité des propriétaires d'automobile.

(4) Sanchez Tejerina, teoria de los delitos de omision.

(5) Anglolini, Dei delitti colposi.

(6) Antonio CaSes, Lesiones por automovil (Madrid, 1932), pg. 25.

(7) Le vie d'Italia, Fevereiro de 1933, artigo intitulado "A segurança do trafego aereo".

(8) A. Cases, loc. cit., pags. 18,50 e 51.

(9) Codigo Civil anotado.

(10) Revue Trimestrel de Dr. Civil, vil. 7.๑

(11) Loc. cit., pg. 30 .

(12) Baudry de Saulnier, prefácio do livro de J. Imbrece, L'automobile devant la justice.

(13) Colon y Marinón, Compendio juridico del acidente de automovil (Barcelona, 1933), vol. I, pg. 30.

(14) Op. cit., pg. 62.

(15) Cifr. Dic. de jurisprudencia de Vicente Piragibe, verb. crime culposo.

(16) Loc. cit.

(17) Frosali, Reato, danno e sanzioni, (Padua, 1932) pg. 221.

(18) Em Outubro do ano findo foi publicado o Projeto de Codigo Criminal brasileiro, apresentado pela comissão encarregada de rever o projéto Sá Pereira, composta pelo mesmo professor e pelos Doutores Evaristo de Moraes e Bulhões Pedreira. Não era de esperar que altas competencias em direito penal dedicassem tão pouca atenção a assunto de tanta monta. Veio, enfim, o Projeto revisto confirmar a necessidade por nós assinalada no texto, de legislação especial sobre delitos originados do transporte, em particular de automoveis. 